Check for updates

London

Cite this as: BMJ2020;371:m3916 http://dx.doi.org/10.1136/bmj.m3916 Published: 07 October 2020

\title{
Covid-19: Supply chain problems could delay NHS tests
}

\section{Shaun Griffin}

The UK's struggling covid-19 testing system faces further disruption after a failure in the supply chain of critical test kits made by the drug company Roche.

Biomedical scientists have warned that the problem, which is due to a switch to a new warehouse, could also affect testing across a whole range of conditions. This is the second glitch this week to affect England's test and trace system, after an IT system error left 16 ooo tests unreported, leading to an artificially low picture of the spread of the virus and delaying contact tracing efforts. ${ }^{1}$

Roche, one of the main suppliers of covid-19 polymerase chain reaction (PCR) and antibody tests to the NHS Test and Trace system, went live with the distribution of goods from its new national distribution centre in Sussex in September.

A Roche spokesperson told The BMJ, "During the transition, we experienced a number of unforeseen issues which are delaying the dispatch of some products. We deeply regret [the delay] and apologise to any of our customers who have been impacted."

\section{Local contingency plans}

In a letter to customers sent on Monday 5 October Roche said that the disruptions "may not be resolved for 2-3 weeks," advising them to activate local contingency plans and prioritise essential services.

Allan Wilson, president of the Institute of Biomedical Science and a practising biomedical scientist in Scotland, told The BMJ, "A delay of two weeks would put a real strain on the system, as we would have run out of kits. This is a much wider issue than covid testing, as Roche are a major supplier of biochemical test reagents. If we run out we may not be able to perform blood glucose or liver function tests, for example."

He added, "It is my understanding that Roche have introduced an Amazon-style automated system, so it is frustrating that they have supplies but a computer failure means they can't get them out. We started to see problems last week."

Wilson said that his hospital and others had put contingency plans into action, sharing supplies with other local hospitals, and that he was also aware that Roche was moving reagents around the UK.

"However, some labs are getting supplies, but some are not," he said. "It seems to be quite ad hoc."

Derek Hill, professor of medical imaging science at University College London, said that Roche had reconfigured its warehousing ahead of the UK's departure from the EU, to manage the risk of disruption to supply chains. Roche was not prepared to comment on the impact of Brexit.

\section{Daily testing capacity}

Xiaojun Wang, professor of operations management at Bristol University, said that the "supply problems could have a significant impact on the test and trace system depending on the inventory level of swabs, screening kits, and reagents in the labs and how long this supply disruption lasts.”

He added, "This [is] very bad timing when the UK is experiencing a new wave of increasing covid-19 infections and the surging demand for testing. The next few days' test figures need to be closely watched to assess its real impact. It certainly adds more difficulty in achieving the UK's daily testing capacity to 500000 by the end of October."

In a statement issued on Wednesday 7 October, Geoff Twist, general manager of Roche Diagnostics UK and Ireland, said that the current problem "has not and will not affect our commitment to supply covid-19 tests."

"We are confident that the plans we have put in place will deliver significant improvements by the weekend to the supply of the tests affected by these logistical issues," he said. "We will be well on the way to resolution by the end of next week.

"In the meantime we are working closely with the NHS in England, Wales, Scotland, and Northern Ireland, and the HSE [Health Service Executive] in Ireland, to minimise the impact on critical services which rely on our products-including cancer, cardiac and infectious diseases. The supply of Roche medicines is continuing as normal.”

Mahase E. Covid-19: Only half of 16000 patients missed from England's official figures have been contacted. BMJ 2020;371:m3891doi: 10.1136/bmj.m3891.

This article is made freely available for use in accordance with BMJ's website terms and conditions for the duration of the covid-19 pandemic or until otherwise determined by BMJ. You may use, download and print the article for any lawful, non-commercial purpose (including text and data mining) provided that all copyright notices and trade marks are retained. 